\title{
Firmaet Peter Jessen i Aabenraa
}

- en blandet manufakturhandel gennem trekvart århundrede

\author{
af Erik Jessen
}

I 1970-80'erne måtte ikke så få hæderkronede blandede manufakturforretninger i provinsen dreje nøglen om. De havde haft deres tid. I Aabenraa er firmaet Peter Jessen. grundlagt 1911 og ophørt i 1989, et godt eksempel på branchens udvikling. Grundlæggerens søn, fhv. amtsborgmester Erik Jessen, fortæller her firmaets historie med vægten lagt på dets første 42 år.

Beretningen fastholder træk af handelslivets udvikling i Nordslesvig fra før 1. Verdenskrig og frem til i dag. Den viser, hvor stærkt livet $\mathrm{i}$ og omkring forretningerne har ændret sig gennem trekvart århundrede.

Fra $1890^{\prime}$ erne og frem til 1 . verdenskrig oplevede byerhvervene i hele Vesteuropa en stærk vækst. Den omfattede næsten alle brancher, og den nåede også til byerne i Nordslesvig trods deres ringe befolkningsvækst. Den gunstige udvikling gjaldt ligeledes butikshandelen, hvor en række nye og større butikker opstod, og vareudvalget udvidedes og forfinedes i takt med kundernes økonomiske formåen og deraf følgende krav.

Et typisk træk i denne udvikling var etableringen af en række blandede manufakturforretninger, hvoraf flere voksede sig store og fik karakter af varehuse eller magasiner. Vareudvalget var meget bredt, både vare-, kvalitetsog prismæssigt. Den typiske blandede manufakturforretning solgte både dame-, herre- og børnetøj, foruden kjolestoffer og andre metervarer samt syartikler. Hertil kom ofte gardiner, sengetøj og gulvtæpper.

I de nordslesvigske byer er det typisk, at stifterne af disse forretninger var landmandssenner, der ikke fandt plads i landbruget. Som et eksempel på en sådan blandet manufakturhandels udvikling skal her fremdrages manufakturhandler - eller købmand, som han foretrak at betegne sig - Peter Jessens virksomhed i Aabenraa fra 1911 til 1953.

\section{Slægten}

Peter Jessen fødtes den 21. april 1886 i Vellerup i Agerskov sogn i Midtsønderjylland. Her sad hans far, gårdejer Johann Jessen (1834-1926) på den vestligste gård, hvoraf i dag kun stuehuset er tilbage. Johann Jessen var født i Lyders- 
holm, hvor hans far Jacob Jessen (1795-1879) gennem mange år var lærer. Han stammede fra Jessen-slægten i Lovtrup ved Uge.

Johann Jessen blev i to ægteskaber far til 12 børn, hvoraf kun de syv nåede skelsår og alder, og igen kun to blev ældre end 50 år. "Lungesygen «, dvs. tuberkulosen, krævede sit. Johann Jessen kaldtes også Johann Guldgraver eller Johann Australier, idet han som ung havde tilbragt fem år nord for Melbourne i Australien, som guldgraver, skovhugger, tømrer og med at indfange vilde heste. Vel hjemme var han i stand til at købe sig en gård i Bastrup ved Vamdrup nord for den daværende grænse. Men efter hans første kones død førte ægteskab nr. to ham igen til Nordslesvig, til gården i Vellerup, som han købte i 1880. »Johann Jessen var en udmærket dansk mand, naturven og jæger«, skrives der i et eftermæle.

Peter Jessens mor, Elsabe Cathrine Møller (1853-1919) var født på en gård i Øster Højst, men mistede i toårsalderen begge forældre, hvorefter hun blev optaget i familien hos morbroderen, Peter Nissen Terp på Herslevgaard ved Hellevad. Peter Jessen døbtes Peter Nissen Jessen. Peter Nissen-navnet kan i

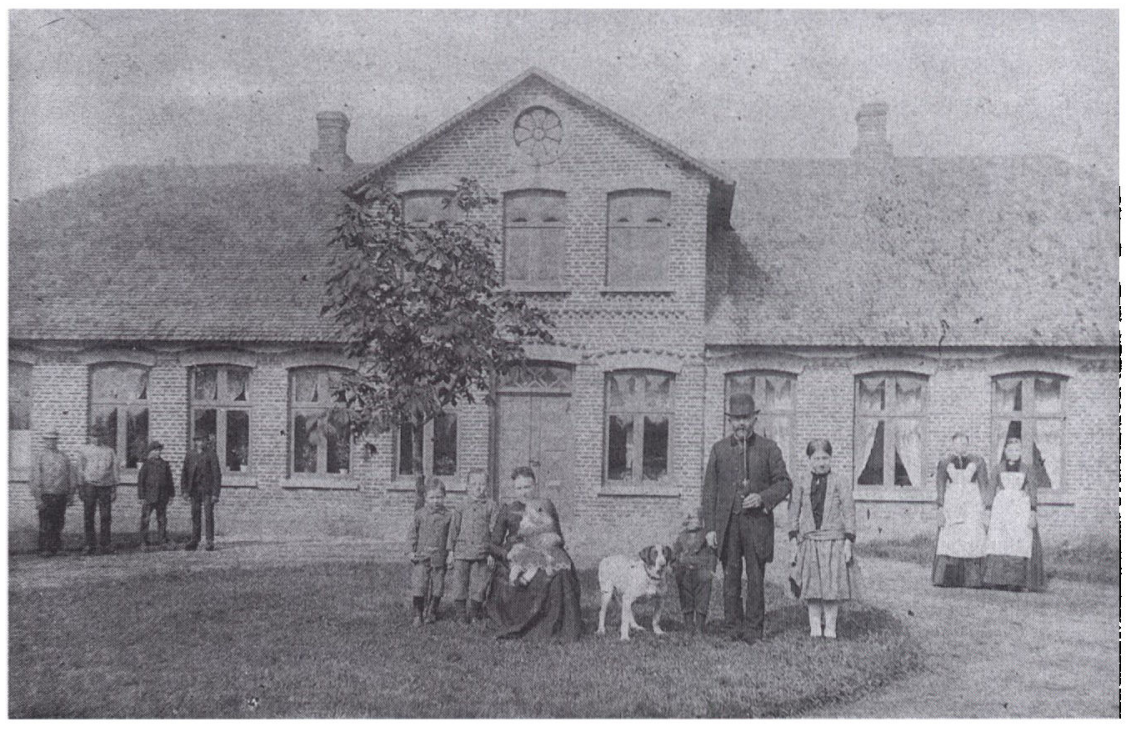

Der var orden $i$ det, da fotografen omkring 1895 besogte gården $i$ Vellerup. Helt til venstre står de to karle, en dreng og daglejeren og til hojre de to piger. I midten er det familien. Fra venstre: drengene Peter og Christian. Siddende: moderen, Elsabe Cathrine Jessen med den yngste datter, Kjestine, kaldet Dinne (senere gift Andresen, Aabenraa). Dernast datteren Johanne, kaldet Haje (senere gift ingenior Niels Hansen, Aarhus), med faderen Johann Jessen $i$ hånden. Sidst står den aldste datter, Anna Margrethe (gift med Jens Moller, Maarbak). Gärden var da pd 68 ha, det mest udlagt til grasning og hoslet. Husdyrholdet bestod af $8 \mathrm{keer}, 46$ stude, ungkvag og kalve, 4-6 svin, 30-40 hons foruden 4 heste og 2 plage. Om vinteren var der ikke behov for drengen og daglejeren. 
slægten spores tilbage til bolsmanden Peter Nissen (1675-1715) i Starup ved Løgumkloster, hvorfra slægten kan føres tilbage til bl.a. bonden og storkøbmanden Peter Beyer på Skastgård. Det skulle vise sig, at der også var købmandsblod i den Peter, der fødtes på gården i Vellerup i 1886.

\section{Uddannelse}

Den 1. april år 1900 kom han, knap 14 år gammel, i lære i Aabenraa hos købmand Peter Clausen på Storetorv, byens største manufakturhandel. Det skete ret tilfældigt foranlediget af en annonce i Hejmdal, men beslutningen om at søge til handelen kan også være inspireret af to farbrødre, der var gået den vej.

Drengen Peter kunne fremlægge gode papirer fra skolen i Bovlund, som han ofte benævnte Bovlund Gymnasium. Han fik "Sehr Gut« i både religion, tysk og regning og »Gut« i alle øvrige fag. »Seine Führung war während seiner Schulzeit gut«, slutter vidnesbyrdet.

Arbejdsdagen var lang. Lærlingene begyndte kl. seks med at gøre rent, så butikken var klar til at åbne klokken syv. Der var åbent, så længe der var kunder også ud på aftenen. Om søndagen skiftedes personalet til at holde vagt, for det tilfælde at en kunde skulle melde sig ved døren. I kirketiden skulle døren være låset, men det var hurtigt at låse den op, hvis nogen tog $\mathrm{i}$ håndtaget!

Hos Peter Clausen fik Peter kost og logi, men så naturligvis ingen løn. Netop år 1900 lod Peter Clausen sin fleretages patricierejendom bygge i Vestergade 8. Her fik Peter i fællesskab med en anden lærling et udmærket værelse øverst oppe. Som mange vil vide, var den kendte malerinde Franciska Clausen en datter af Peter Clausen. Hun fødtes 1899.

Efter fire års læretid og et halvt år som kommis forlod Peter Jessen Aabenraa for at søge videreuddannelse. Som så mange andre unge danske sønderjyder foretrak han at tage sydpå. Det kunne han gøre med en smuk anbefaling fra Peter Clausen i lommen. "Er war stets treu und fleissig und ein tüchtiger Verkäufer«, stod der bl.a. at læse.

I årene fra 1904 til 1910 havde han ansættelse i en række forretninger som Verkäufer. Det var hos Holmfeldt på Markplatz i Husum, Helmer og Jørgensen på Perlegade i Sønderborg, Mau og Andresen, der netop da havde opført den nye butiksejendom på hjørnet af Holm og Nikolaigade i Flensborg, og hos Rudolph Karstadt, først i Kiel til en månedlig løn af 140 mark, og siden i Lübeck. "Derselbe war fleissig und hat mir durch seine Leistungen immer zufriedengestellt« hedder det $i$ en anbefaling herfra. 
Så tilfredse var Mau og Andresen nu ikke, for dér blev Peter Jessen med øjeblikkelig virkning afskediget. Han havde, efter chefens opfattelse, ikke opmærksomt og omhyggeligt nok betjent en kunde. I 1907 indkaldtes Peter Jessen til militærtjeneste, men hjemsendtes efter en måneds tid. Han led ofte af bronchitis og kunne ikke klare de fysiske krav.

\section{Start i Aabenraa}

I 1910 drog Peter Jessen atter nordpå. For anden gang tiltrådte han en stilling hos Helmer og Jørgensen i Sønderborg. I løbet af det følgende år orienterede han sig om muligheden for at leje et passende butikslokale og fik tilbud fra Tinglev, Tønder, Sønderborg og Aabenraa. Fra de to sidstnævnte byer lå der flere tilbud, hvoraf han foretrak et af tilbudene fra Aabenraa. Det drejede sig om et lokale i ejendommen Storegade 5, hvor tidligere det mondæne Hotel Phønix havde haft til huse. Med ejeren, møbelhandler August Rasmussen, sluttede han en fem års kontrakt om leje af et butikslokale og et par værelser til en årlig husleje af 3000 mark. Aabenraa havde da 7.800 indbyggere og et solidt opland.

Han havde selv sparet 6000 mark op. Hos familie lånte han andre 6000 mark og ved henvendelse til Den Nordslesvigske Folkebank fik han tilsagn om »den fornødne kredit mod de opgivne kautioner«. Kautionisterne kendes ikke, men det har sikkert været familiemedlemmer. Aftalen med Den Nordslesvigske Folkebank blev indledningen til et livslangt positivt samarbejde.

Efter foretagne indkøb og indretning af facade og butik kunne den nu 25årige Peter Jessen åbne sin butik den 5. september 1911. Det skete ved to efter datidens forhold meget store annoncer, hvoraf den ene var en tilbudsannonce: "med neden-stående i Berlin fordelagtigt indkøbte artikler«, der samtidig markerede, at den nye købmand lagde vægten på konfektion, dvs. færdige varer fremfor det, der dengang var almindeligt: at købe stof og lade det sy eller selv sy det. Peter Jessen var ikke i tvivl om, at tendensen ville gå i retning af færdigvarer, såsom kjoler, bluser og nederdele.

Det blev hans politik at indkøbe mest muligt direkte hos fabrikanter og så vidt muligt undgå grossister, hvorved han mente at kunne opnå både en lavere pris og den mest aktuelle mode. Det var også hans tanke gennem en koncentration af indkøbene i så høj grad som muligt at sikre sig eneforhandling $i$ byen af bestemte fabrikater. Han afviste at deltage i indkøbssammenslutninger. Han ville selv udsøge de varer, han ønskede at tilbyde sine kunder og lagde vægt på at føre de nyeste og mest moderigtige varer, der kunne sælges til en rimelig og overkommelig pris. Som reklame benyttede han avisannoncer, 

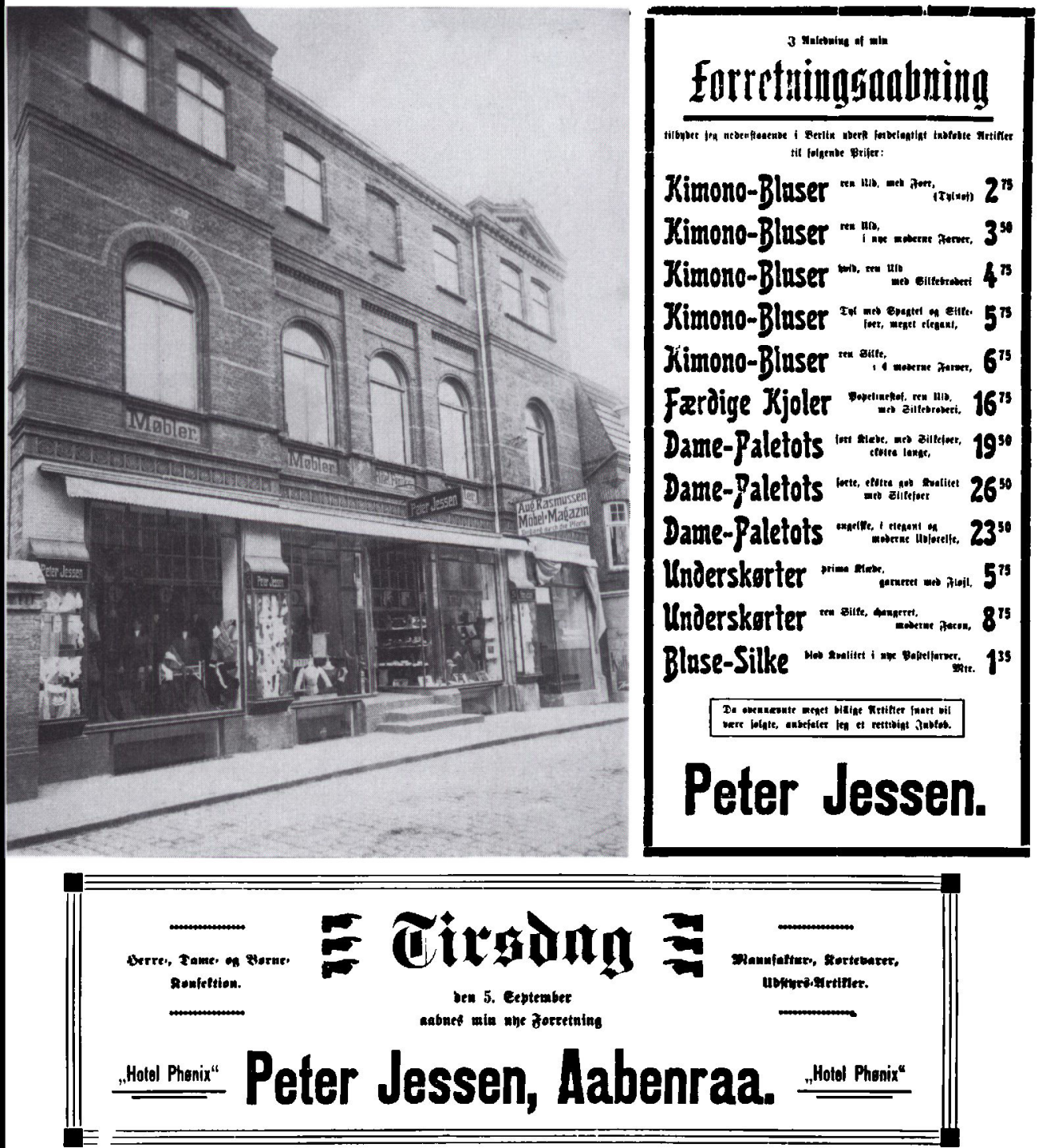

Peter Jessens forste butik, Storegade 5. Der er tre store udstillingsvinduer og udhangsskabe på de barende piller. De to abningsannoncer var store henholdsvis $15 \times 45 \mathrm{~cm}$ og $20 \times 45 \mathrm{~cm}$. Priserne er $i$ mark, der da stort set svarede til kroner. Foto 1911. H. Nedell, Aabenraa.

ofte store og slagkraftige annoncer. Det blev disse strategier, der førte forretningen frem og sikrede den en stadig større kundekreds og stigende salg. 
Starten blev god. Den første dag var der 450 mark i kassen og de følgende omkring 300 mark. Salget lagde sig hurtigt fast på omkring 300 mark om dagen, men i dagene omkring den første november, der var skiftedag, røg det op på 600 mark. Det samme salg opnåedes også nogle dage i december måned. Der foreligger ingen regnskaber for de første år, men ud fra en eksisterende kassebog må det skønnes, at de første tolv måneders salg blev på godt 100.000 mark. Personalet omfattede til at begynde med en kommis og en lærling, og desuden hjalp Peter Jessens to søstre, Johanne og Kjestine med i forretningen.

Men den unge købmand fandt også tid til private sysler. Den 10. juli 1912 forlovede han sig med Anna Hansen, datter af købmand Lorenz Hansen og hustru Ingeborg. Derved kom han ind i en af byens gamle danske, konservativt prægede familier. Anna havde seks søskende, hvoraf de fire med ægtefæller og børn var bosat i Aabenraa. Det var familierne tandlæge Johannes Hansen, købmand Hans L. Hansen, isenkræmmer Lorens Hansen og amtslæge Mads Michelsen. En generation længere tilbage omfattede familien i Aabenraa bl.a. havnefoged Jacob Jacobsen, nellikegartner Christian Jacobsen og gårdejer Valdemar Jacobsen i Nygade. Der gik slægtstråde til gårdejerfamilien Michelsen i Kolstrup. I februar 1913 stod brylluppet, og i februar 1914 fødtes ægteparrets første barn, datteren Ingeborg.

\section{Krigstid og start påny}

Men $i$ august samme år begyndte verdenskrigen, og denne gang skulle heller ikke den nybagte far slippe. I slutningen af marts $1915 \mathrm{kom}$ indkaldelsen, og han måtte overlade forretningens førelse til søsteren Kjestine, der sammen med Anna Jessen og fornøden medhjælp holdt forretningen $i$ live i krigsårene med varemangel og rationering.

Efter en militar uddannelsesperiode i Bielefeldt var Peter Jessen så heldig at komme til den russiske front og undgik derved de blodige kampe på vestfronten. I lange perioder var han stationeret $i$ skovene $i$ nærheden af Wilna (nu Vilnius, hovedstad i Litauen), hvor han gjorde tjeneste ved en telegrafbataljon. I december 1918 vendte han hjem til Aabenraa som så mange andre menige benådet med jernkorset af 2 . klasse.

Under de tre og et halvt års krigstjeneste havde Peter Jessen ikke mistet interessen for forretningen. Under orlovsrejser gjorde han ophold i Berlin og Hamborg for hos leverandører dér at orientere sig om muligheden for leverancer, og i september/oktober 1918 korresponderede han med sin svigerfar, købmand Lorenz Hansen, om muligheden for at købe en butiksejendom i Aabenraa. I oktober anbefalede Lorenz Hansen ham ejendommen Storegade 
17. Det var en nærmest saneringsmoden toetages bygning, men meget centralt beliggende vis-a-vis Den Nordslesviske Folkebanks bygning fra 1912. Straks efter hjemkomsten købte Peter Jessen denne ejendom af købmand P.W.Clausen (ikke at forveksle med Peter Jessens tidligere chef, købmand Peter Clausen). Familien flyttede straks ind $\mathrm{i}$ en lejlighed $\mathrm{i}$ bagbygningen. Prisen for herligheden var 65.000 mark.

I 1919 oprettede Peter Jessen også en filial i Gram. Den havde to formål. Det ene var at sikre søsteren, Kjestine, der på dygtig vis havde hjulpet forretningen gennem krigsårene, en levevej, det andet at sikre faderen gode forhold. Moderen døde i maj 1919, og gården var tidligere blevet overdraget den ældre bror, Christian. Filialen i Gram opretholdtes indtil 1926, da faderen døde, og søsteren samtidig indgik agteskab.

Den mest påtrængende opgave var dog at fremskaffe varer til den tomme butik. Kundernes behov var stort efter de fire trange krigsår, hvor fornyelse af tøj og af hjemmets textiler kun i ringe omfang havde været mulig. Anmodningen om vareleverancer afgik $i$ første omgang til de traditionelle tyske leverandører, men efterhånden som genforeningen nærmede sig, orienterede

Filialen i Gram fra 1919 til 1926 havde ét vindue til Slotsvej. Fra 1. sal var der udsigt over slotsparken.

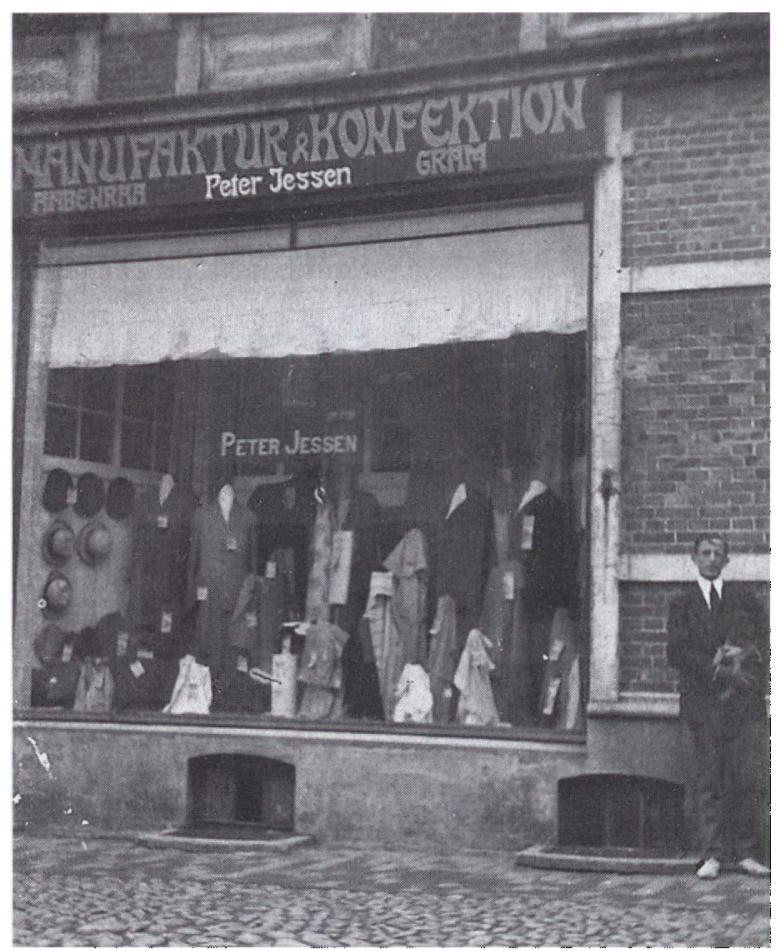


Peter Jessen sig naturligt nok $\mathrm{i}$ stigende omfang om de muligheder, som Danmark gav.

I marts 1919 deltog han i sønderjyske købmænds studieophold i København. I den uge studieopholdet varede, knyttede han forbindelse til leverandører $\mathrm{i}$ København, ligesom han i det hele undersøgte danske butikkers varesortiment, priser og butiksindretning. Det skete også på en række småture til Kolding. Både dér og i København købte han, i detailforretninger, en del varer, bestilt af varehungrende kunder, med hjem.

Den efterfølgende genforening i 1920 betød ikke nogen total ændring i den hidtidige leverandørkreds. Peter Jessen opretholdt $\mathrm{i}$ årene derefter samhandel med mange tyske forbindelser, der dog nu blev suppleret med ikke alene danske, men også britiske og franske. De foretrukne indkøbsbyer blev herefter Berlin, Stuttgart, Hamborg, Düsseldorf, Gera, Krefeldt, samt London, Bradford og Manchester, foruden naturligvis København og en ganske lang række danske provinsbyer.

\section{Byggeri}

Den særlige opgave først i 20 'erne blev dog opførelsen af den nye forretningsejendom på Storegade 17. Grunden havde 17 meter facade til Storegade og var godt 100 meter dyb, sluttende med facade også mod Madevejen. Det toetages hus mod Storegade, der skulle nedrives, indeholdt fem lejligheder foruden nogle butikker. Nedrivnings- og byggetilladelse forudsatte, at bygherren som erstatning etablerede fem andre lejligheder. Det skete delvist $\mathrm{i}$ andre ejendomme. Som arkitekt blev valgt Niels Jacobsen, Odense, der var en morbror til Anna Jessen. Han var barnefødt i Aabenraa og en anerkendt arkitekt, der især i Odense har opført en rakke markante bygninger, bl.a. Grand Hotel, Odense Teater, en del skoler og pengeinstitutter samt Fyns Forsamlingshus. I Aabenraa var det Den Nordslesvigske Folkebank og Sct. Jørgens Kirke.

Den nye forretningsbygning blev på tre etager foruden kælderlokaler, tilpasset nabo- og genboejendommene. I stueetagen blev der et butiksareal på godt $300 \mathrm{kvm}$ og i kælderen ca. $140 \mathrm{kvm}$. Hertil kom lokaler til kontor, systue, lager, fjerkammer og anden service. Den eksisterende to-tre etages bagbygning bibeholdtes og sammenbyggedes med den nye bygning. I bagbygningens underetage indrettedes en lejlighed til huskarl Jørgen Jacobsen og hans familie, hustru og seks børn. Huskarlen førte tilsyn med ejendommen og renholdt gård og gade. Han anvendtes også som bybud og havde her en trækvogn med to store hjul til rådighed. På første og anden sal i det nye forhus indrettedes den 

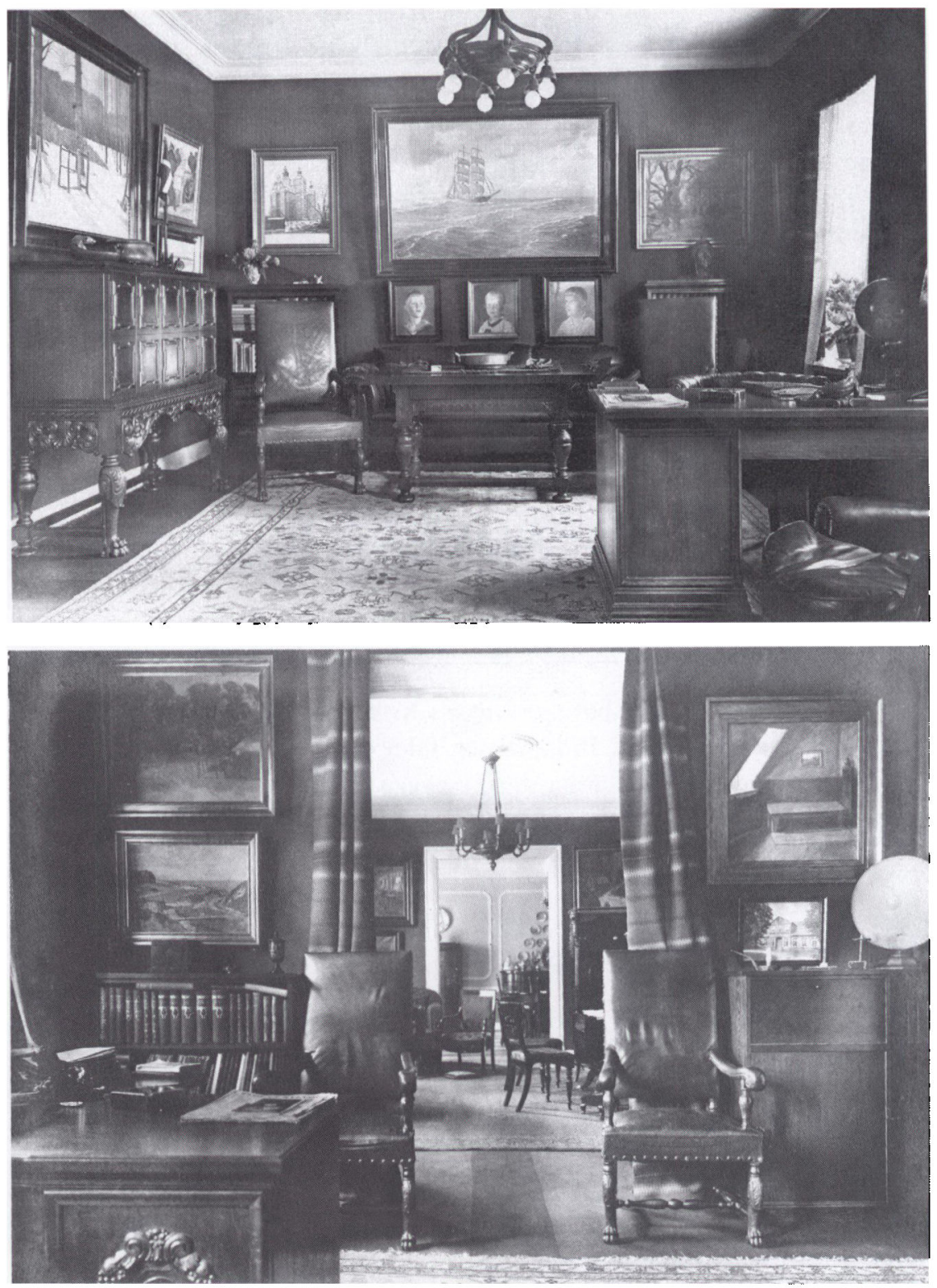

To billeder fra købmandens lejlighed på Storegade 17. Overst herrevarelset med de tunge egetrasmobler. Til venstre tobaksskabet med de gode cigarer og på vaggen maleren Petersen Stubbaks portratter af sonnerne, fra venstre Erik, Olaf og Johan. Nederst et kig gennem alle tre stuer. Forrest herrevarelset. Skabet til højre gemte en radio med hojtaler. Damevarelset i midten, også kaldet dagligstuen, var mobleret med mahognimobler. Spisestuen skimtes bagest. Moblerne var af lyst birketra, og der kunne dakkes til 24, hvis man sad tat til 30. 
private lejlighed med ca. $130 \mathrm{kvm}$ i hver etage. På første sal var der tre stuer til gaden, herreværelse, dameværelse og en spisestue, hvor der kunne dækkes til 24, når bordet var trukket ud. Mod gården indrettedes køkken og et alrum, der både var legeværelse og daglig spisestue. På anden sal var der forældresoveværelse, børneværelser, pige- og gæsteværelse foruden badeværelse. Der hørte både kokke- og stuepige til, og børneflokken voksede. Foruden Ingeborg, der fødtes i 1914, var der drengene Johan (1915), Erik (1919), Olaf (1922) og Peter Christian (1925).

Der var altså tale om en stor og herskabelig lejlighed, der var indrettet både til familiens daglige behov og til gaster og selskabelighed. Det var dengang ret almindeligt, at chefen boede nær virksomheden, hvilket havde den fordel, at chefen let kunne skifte mellem virksomhed og privaten, f.eks. til måltider og måske en middagssøvn. Men det skabte også mulighed for, at kunder ved henvendelse til den private dør kunne blive betjent uden for åbningstiden. Det opfattedes af begge parter som en naturlig service.

For at gennemføre byggeriet indhentede Peter Jessen tilbud på murer-, tømrer-, snedker- og blikkenslagerarbejdet under ét hos tre lokale firmaer. Til byggeriet antoges Brdr. Jensen, der afgav et tilbud på de nævnte entrepriser på knap $82.000 \mathrm{kr}$.

Spejle indkøbtes i Flensborg, inventar i København og hos lokale snedkerfirmaer. Samarbejdet med Brdr. Jensen faldt så positivt ud, at Peter Jessen siden altid anvendte dette firma til sine byggeopgaver.

\section{Den nye butik}

Den 11. december 1923 kunne Peter Jessen byde velkommen i de nye butikslokaler, der allerede i september 1924 udvidedes med en speciel afdeling for herre- og drengetøj i lejede lokaler i naboejendommen Storegade 19. Den butik, Peter Jessen herefter kunne præsentere med hovedvægten lagt på damekonfektion og kjoler, var en blandet manufakturhandel med fuldt varesortiment og indrettet efter tidens nyeste principper, afdelingsvis opdelt.

Til højre for indgangen fandtes kasse og vareudlevering. Langs væggene til højre: loftshøje reoler med kjolestoffer på træhylder og stiger til rådighed, så også de øverst liggende varer kunne nås. Til venstre for indgangen fandtes småting, uldgarn og syartikler og langs væggene her hvidevarer, dvs. lagenlærred, dynebetræksstof og dynebolster og den slags foruden håndklæder og duge. Midt foran indgangsdøren fandtes dameundertøj, strikvarer, handsker, paraplyer m.m., det meste opbevaret i skuffer eller på hylder med glas foran. Damefrakker, kjoler, bluser og nederdele fandtes bag i lokalet, hvor kjolerne 
hang på bøjler bag glasskydedøre, mens frakker hang på fritstående stativer. I kælderetagen solgtes gulvtæpper og tæppetøj, overvejende Gram- og Højertæpper, men også udenlandske Axminster- og Wiltontæpper. Også linoleum solgtes her og dyner m.m. Afdelingen for herre- og drengetøj fremstod som en butik for sig selv med egen indgang fra gaden, men dog også med forbindelse til det øvrige butikslokale gennem en overdækket »bro«, der af medarbejdere spøgefuldt kaldtes »sukkenes bro«.

Den her skildrede udvikling og søsterens etablering i Gram medførte ansættelse af flere medarbejdere. I 1919/20 ansattes således Johannes Andresen, der siden udnævntes til prokurist og blev Peter Jessens højre hånd i godt tyve år, Georg Petersen, der efterhånden overtog ansvaret for kontorfunktionerne og ligeledes fik prokura, og Peter Sørensen, der overtog ledelsen af herre- og drengeafdelingen. Hertil kom den myreflittige Maren Madsen, der ledede systuen, hvis opgave var at foretage forandringer og tilpasse tøjet til kunden, men som også syede gardiner, hvidevarer, børnetøj m.v. De tre sidstnævnte blev firmaets betroede medarbejdere gennem mere end 40 år, indtil de holdt op på grund af alder.

Økonomisk var Peter Jessen kommet godt igennem krigsårene og overgangstiden fra tysk til dansk. Det ses ikke, at han har haft hverken store tab eller nogen særlig fortjeneste ved mark/kroneændringerne. Da han første gang, i 1920, opgør sin formue i kroner, er den på $131.000 \mathrm{kr}$., hvorefter den stiger smukt og i 1925 er vokset til $400.000 \mathrm{kr}$. I årene 1926 til 28 følger en nedgangsperiode, der formentlig kan tilskrives kronedevalueringen, arbejdsløsheden og landbrugskrisen, der ramte det genforenede Sønderjylland hårdt. Men i 1929 når formuen igen de 400.000 . Her foreligger også nogle tal for salget, der $\mathrm{i}$ 1926 topper med $700.000 \mathrm{kr}$., for de følgende år at falde til omkring 500.000, men i 1934 passerer salget igen de 700.000 for i 1939 stærkt at nærme sig den sikkert attraktive million.

Til forståelse af den opsparing, der her finder sted, er det nødvendigt at vide, at skattebyrden dengang, i modsætning til i dag, var lidet tyngende. I skatteåret 1923/24 betalte Peter Jessen således i alt 5.900 kr. i stats-, kommuneog kirkeskat og i 1936/37 i alt kr. 12.100. Det er også vigtigt at forstå, at prisniveauet i disse år var ret stabilt, således at det stigende salg overvejende er udtryk for en reel omsætningsforøgelse og ikke for prisstigninger. Endelig bør det huskes, at omkostningsniveauet var væsentlig lavere end nu. Eksempelvis kan nævnes, at timelønnen for en typograf i 1934 var $1,74 \mathrm{kr}$., og at en lærer i 1941 havde en årsløn på 5-5.500 kr. 


\section{Sønderborg - initiativ}

Victor Johannsen, der var søn af Peter Jessens skolelærer i Bovlund, drev i en årrække en manufakturforretning på Rådhustorvet i Sønderborg. Den omdannedes i 1924 til et aktieselskab under navnet Johannsen og Reinemer A/S med Johannsen som leder og Reinemer med flere som passive aktionærer. Kort tid efter indskød Peter Jessen 35.000 kr. i selskabet for i 1926 at købe de fremmede aktionærer ud, hvorefter han ejede aktiemajoriteten med Victor Johannsen som eneste anden aktionær. I 1937 indstillede selskabet sin virksomhed. Det havde ikke været muligt at drive forretningen med et rimeligt resultat. Det er uklart, om Peter Jessen investerede i denne forretning med henblik på også i Sønderborg at udvikle en større forretning, eller om det var venskabseller familiebånd, der motiverede investeringen. Victor Johannsen, der efterfølgende i mange år med bopæl i Aabenraa virkede som repræsentant for et anerkendt herrekonfektionsfirma, var vokset op i Bovlund og var svoger til Peter Jessens bror Christian.

\section{Nye udvidelser}

Der var nu ellers nok at se til for den driftige købmand hjemme i Aabenraa, hvor et stigende salg og et stadigt større antal medarbejdere stillede krav. I 1929 fulgte en mindre udbygning af butikslokalerne på stueplan for at skaffe plads til den hurtigt voksende kjoleafdeling.

Allerede i 1932 fulgte et stort nybyggeri, idet der mod øst i forlængelse af den gamle bagbygning opførtes en treetages bygning, hvor hver etage var på ca. $110 \mathrm{kvm}$. Underetagen, der her lå over terræn, anvendtes foruden til en udvidelse af huskarl Jacobsens bolig til en ny gardinafdeling. Stueetagen anvendtes til damekonfektion, ligesom der her indrettedes et par kontorlokaler. 1. sal blev anvendt til systuer, idet Peter Jessen udover den tidligere nævnte forandringssystue nu også oprettede en systue, der udelukkende udførte kjolesyning efter bestilling. Han fandt, at der var behov for denne særlige service over for de kunder, der ikke lod sig tilfredsstille af færdige kjoler. Systuen viste sig imidlertid vanskelig at drive uden tab, hvorfor den efter få års virksomhed ophørte. En samtidig udvidelse af herre- og drengeafdelingen gennem leje af et yderligere areal i Storegade 19 øgede denne afdelings areal til godt $200 \mathrm{kvm}$, og i naboejendommen mod nord, Storegade 15, lejede Peter Jessen hos slagtermester Max Petersen lokaler. Han lod her indrette udstilling af især gulvtæpper og gardiner. Den blev som herreafdelingens facade bygget som en cawneer-facade, hvilket vil sige, at vinduer og indgangsdør blev trukket 

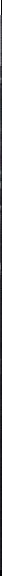

a. Billeder fra butikkens interior efter udvidelsen i 1932. Overst til venstre et kig ind i butikslokalet set fra hovedindgangen. Tv. bomuldsstoffer, derefter skab med paraplver og diske og skabe med damestromper og undertoj. Langere tilhage igen dameundertoj og damestrikvarer bag glas. Th. disk med småting. syartikler m.v. Den sidste store nyhed: lynlăse fremvises pà et stativ.

b. Overst til hojre. Kjoleafdelingen $i$ stueetagen. De fleste kjoler hang i skabe med glasskydedore foran. Th. skab med lange kjoler, og uldne kjoler pä fritstående stativ. Midtfor udstilling af dameundertoj som reklame for lingeriafdelingen. Gulvet er morkebrunt linoleum, moblerne inspireret af Bauhaus' enkle stil.
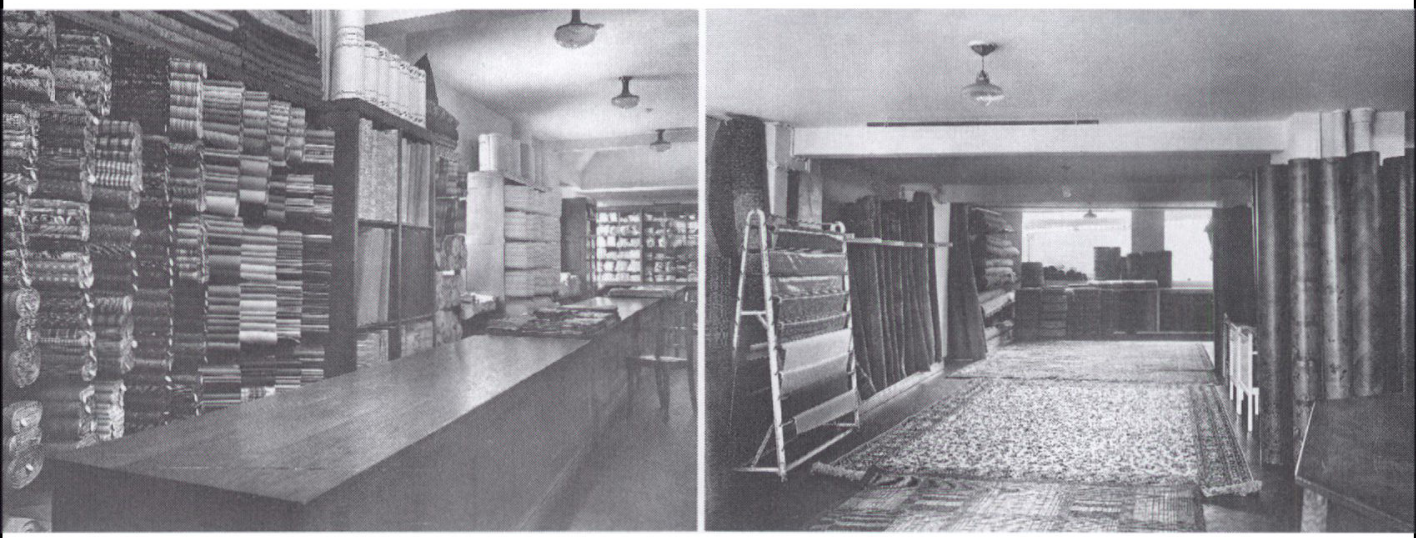

c. Til venstre for indgangen fandtes homuldsstoffer m.v. Forrest på hylden ses ternede. blomstrede og ensfarvede homuldsstoffer, derefter dyneholster, dynebetrakstoffer og händkladestoffer. Derefter hvidevarer: larred og damask til dynebetrak, lagner og pudevar. Bagest skahe med duge, servietter og handklkder. Overst tv. ligger vattapper og efterfolgende: viskestykkestoffer. Det var for selvbetjeningens tid, dog er der fremlagt en del rester til kundens eget valg.

d. Tappeafdelingen $i$ underetagen. Tv. stativ med voksdug, dernast fardige gulvtapper. De store tapper ligger pà hylder. Midtfor tappestof. der almindeligvis var enten 70 eller $90 \mathrm{~cm}$ brede og kunne sys sammen til store tapper. Foran th. linoleum og hag dette: harnesenge og dyner. Til are for fotografen er fremlagt et härgarnstappe og to Wiltontapper. 
tilbage fra gadefronten, så kunder kunne gå og betragte de udstillede varer under tag.

Som nævnt købte Peter Jessen en forholdsvis stor del af sine varer direkte hos udenlandske fabrikker. Da folketinget i 1932 indførte strenge importbegrænsninger, der styredes gennem valutacentralen, måtte han i stort omfang omlægge sine indkøb til danske fabrikker og grossister, ligesom han opmærksomt måtte følge, om han nu også fik de importtilladelser, hans tidligere import og den voksende omsætning kunne motivere. Det var et betydeligt administrativt arbejde for valutacentralen og for den enkelte importør. Men politikerne opnåede det, de ønskede: at begrænse importen og styrke dansk industri, hvor bl.a. textilindustrien fik et vældigt løft.

\section{Private investeringer}

Der blev også tid til at tænke på familiens forhold. I 1926 lod Anna og Peter Jessen således bygge et lille stråtækt sommerhus ved den dengang ret ukendte Vejers Strand på den jyske vestkyst. »Børnene har godt af vesterhavsluft«, lød familielægens kloge råd.

I midten af 30'erne øgedes familiens ønske om at flytte ud fra bymidten. I 1935 købte Peter Jessen et fire tønder land bakket areal ved Posekær syd for

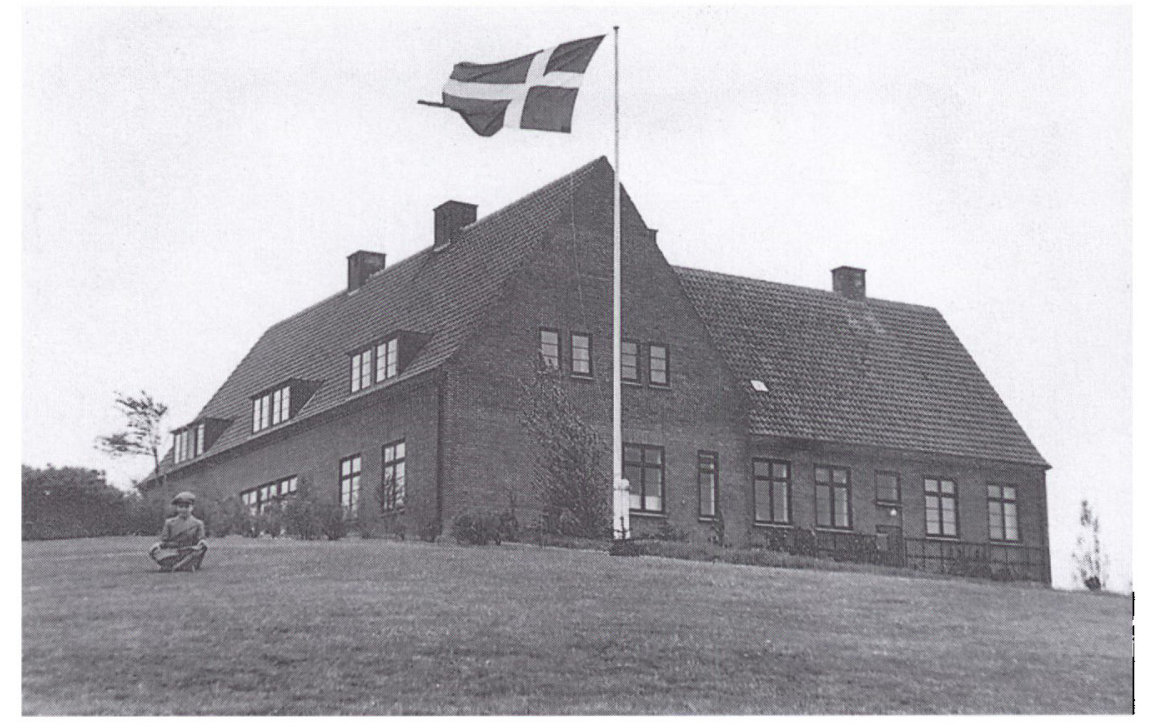

Villaen Bramshjerg er netop bygget, og haven nyanlagt. Foto 1936. 
byen. Det lå dengang uden for det egentlige byområde. Det var næsten som at flytte på landet.

På grunden blev opført en stor rødstensvilla, tegnet af arkitekt Niels Axel Jacobsen, Odense, en søn af tidligere nævnte arkitekt Niels Jacobsen. Arealet, der kaldtes Bramsbjerg, vistnok affødt af, at der var mange brombærbuske i de levende hegn, udlagdes som en parklignende have, køkkenhave og naturareal. Der afsattes plads til en tennisbane, der dog aldrig blev udført. Med bygningen af Bramsbjerg opfyldtes en drengedrøm hos Peter Jessen. Da han som 14 årig sendtes i lære, var det hans tanke at tjene så mange penge, at han kunne købe sig en gård og blive landmand. Da han nåede så vidt, at det kunne realiseres, blev det ikke til en gård, men til den herskabelige villa $\mathrm{i}$ landlige omgivelser med en prægtig udsigt over Aabenraa fjord".

\section{Salg engros}

Familiens udflytning åbnede mulighed for at lejligheden kunne inddrages til forretningsformål. Til 1.sal flyttede kjoleafdelingen, og hertil flyttedes også en afdeling for damehatte, der gennem mange år blev ledet af modist Ellen Rasmussen.

Som så mange andre store forretninger solgte Peter Jessen også varer til mindre forretninger, fortrinsvis i stationsbyer og landdistrikter. Det skete med fradrag af en rabat. For de mindre forretninger var fordelen, at de undgik investering i langsomt omsættelige varer. For sælgeren var fordelen, at dette mersalg kunne gennemføres uden de store omkostninger, idet bestillingerne almindeligvis indgik telefonisk. Det opnåede mersalg kunne endvidere medføre, at sælgeren opnåede bedre betingelser hos leverandører f.eks. køb til engrospriser, øgede rabatter, bonus eller andre fordele.

Det var ikke ualmindeligt, at rutebilvognmænd og syersker i landdistrikterne foretog indkøb af varer efter bestilling fra lokale folk, der ikke selv ønskede at tage til byen for at købe ind. Denne kommissionshandel blev aldrig omfattende, men løste et praktisk problem for mange og betød en kærkommen tillægsindtægt for vognmanden eller syersken.

For Peter Jessen blev engroshandelen ganske omfattende. Først i 30'erne havde den vokset sig så stor, at prokurist Christian Beck udelukkende koncentrerede $\sin$ arbejdskraft om den afdeling, der da fik et selvstændigt lager $i$ kælderetagen, ligesom Christian Beck så småt begyndte at rejse ud for at sælge til andre forretningsdrivende. I de første år var vareudvalget især dame- og børneundertøj, samt strømper og strikvarer. Engrosafdelingen fik i 1935 større lokaler på 2. sal, og Peter Jessen oprettede samtidig et aktieselskab, Aabenraa 
Manufakturlager A/S, med en aktiekapital på $100.000 \mathrm{kr}$. Hurtigt efter fulgte ansættelsen af flere medarbejdere og repræsentanter, og salgsområdet udvidedes til at omfatte store dele af Jylland og Fyn.

\section{Det indre liv}

Billederne til denne artikel giver et indtryk af, hvorledes en moderne, stor blandet manufakturhandel var indrettet $\mathrm{i}$ trediverne. Beklageligvis ses der hverken kunder eller medarbejdere på billederne, selvom det var dem, der skabte liv i lokalerne.

Forretningen var vokset op fra en beskeden begyndelse med nogle få medarbejdere til en ganske stor medarbejderskare, der blev udvidet efter behov. Peter Jessen var den centrale person, "chefen « som han kaldtes. Han var den daglige leder, der aktivt deltog i køb og salg, ved ansættelse af nye medarbejdere, ved inventaranskaffelser og ombygninger og ved reklamefremstød og udarbejdelse af annoncer. Hans teoretiske baggrund var lille. Han var den praktiske mand, der havde dannet sig en mening om, hvordan hans forretning skulle drives $\mathrm{i}$ de ti år, han havde været ansat $i$ ikke færre end seks forskellige, men alle anerkendte forretninger.

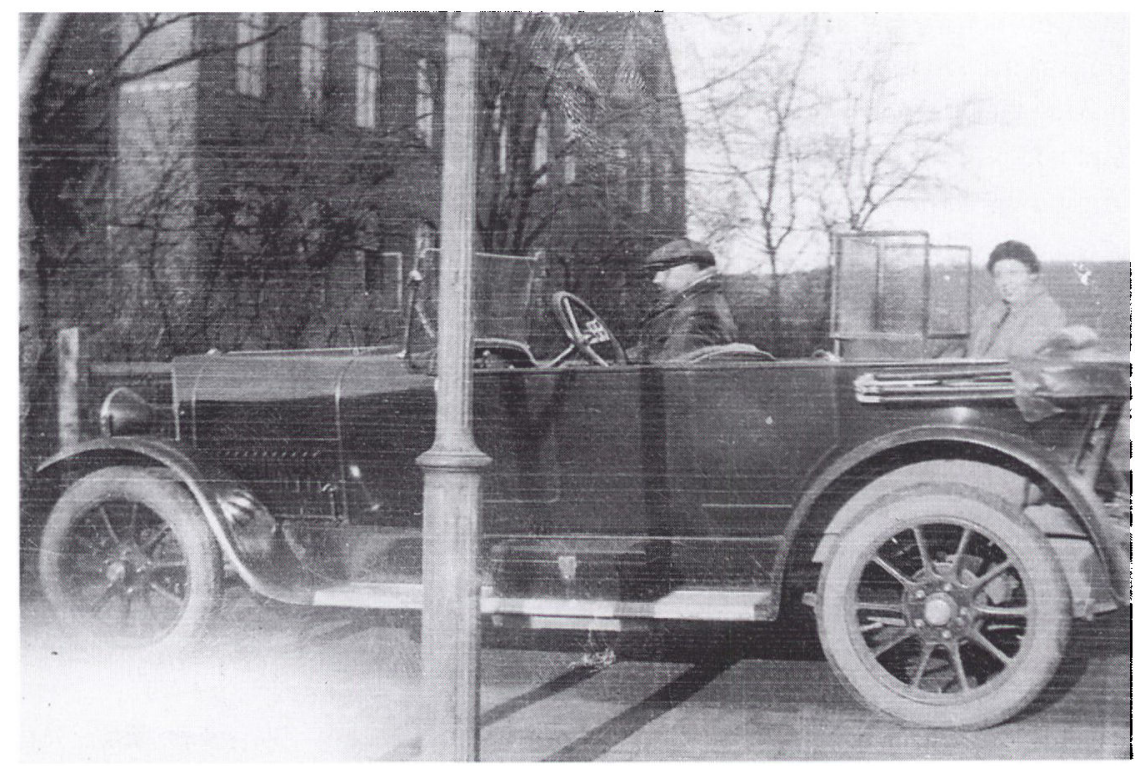

Peter Jessen holdt meget af biler. Her sidder han ved rattet i den forste, en Brennabor, som han kobte i Hamborg i 1921. Anna Jessen er henvist til bagsadet. Foto 1925. 
Efterhånden som forretningen voksede, blev flere opgaver delegeret til ledende medarbejdere, men chefen fulgte med interesse alle større dispositioner. Der forelå ingen skriftlig organisationsplan. Nye medarbejdere gled hurtigt ind på deres pladser og lærte snart, »at sådan gør vi her hos Peter Jessen«. Forholdet mellem chef og medarbejdere kan vel bedst beskrives som et holdarbejde med chefen som den respekterede leder, hvis ord i sidste ende var lov.

Det er nok for meget at sige, at forholdet var patriarkalsk. Snarere eksisterede der den naturlige distance mellem chef og medarbejdere, der følger af det at være ejer, og det at være ansat. Sikkert er Peter Jessen af mange medarbejdere blevet vurderet som en kravende chef, der forventede et flittigt medarbejde, og fuld loyalitet over for firmaet og dets interesser. Arbejdsdagen var lang. Forretningen åbnede om morgenen klokken otte og lukkede klokken atten, dog var der fredag åbent til klokken tyve og lordag til klokken 21. Weekendlukning indførtes først under besættelsen. Den lange arbejdsdag blev afbrudt af to »kaffepauser« og en længere middagspause hver dag. Om middagen gik de fleste hjem eller til pensionatet for at spise den varme mad, der dengang traditionelt blev serveret midt på dagen. Lærlinges arbejdsdag var endnu længere, idet de $\mathrm{i}$ vinterhalvåret de første fire dage $\mathrm{i}$ ugen hver aften måtte tilbringe op til to timer på handelsaftenskolen.

Det nære samarbejde mellem chef og medarbejdere medførte kun i særlige tilfælde privat samvær $\mathrm{i}$ chefens hjem. Men ved jubilæer, runde fødselsdage og ved andre lejligheder afholdtes personalefest, ofte på Grand Hotel, med middag og dans. Her deltog også almindeligvis ægtefæller og faste forlovede.

Medarbejderne var ikke, som det i dag er almindeligt, medlemmer af en faglig organisation. Der fandtes derfor heller ingen overenskomster om løn og arbejdstid. Arbejdstiden svarede til åbningstiden med fradrag af pauser og tillæg af den fornødne tid til oprydning. Overarbejdsbetaling kendtes ikke, men der kunne ved juletid eller ved andre særlige lejligheder være tale om udbetaling af et gratiale. Lønninger aftaltes individuelt, men der eksisterede et mønster i branchen. Skal vi prøve en sammenligning, fik unge medarbejdere løn på linie med unge postbude, og ældre medarbejdere løn på linie med en folkeskolelærer, dog uden deres sikkerhed som tjenestemænd og pensionsordning. Kvindelige medarbejdere fik typisk ti til tyve procent mindre end mandlige. De var jo ofte ugifte og uden forsørgerforpligtelser.

Den afdelingsvise opdeling, der udvikledes i takt med firmaets vækst, var nærmest af ordensmæssig karakter. Normalt blev en kunde betjent "hele vejen rundt « af samme ekspedient eller ekspeditrice, med mindre andet fandtes naturligt, f.eks. at kvindelig betjening var ønskelig, eller der var behov for særlig fagkundskab f.eks. ved salg af gulvtæpper, dyner, pelse eller kjoler m.v. Kunde- og købsmønsteret var en del anderledes end nu, idet en forretning som 
Peter Jessens havde mange faste kunder, familier, der købte den største del af deres forbrug $i$ textiler dér. Ofte knyttede en kunde sig til en bestemt ekspedient og ventede gerne, indtil han eller hun blev ledig. Mange familier, især landbofamilier samlede deres indkøb og købte kun ind et par gange om året, hvor man foretog samlede indkøb til familiens og hjemmets behov. Det var indkøb, der kunne tage flere timer, og stole blev sat frem. Var manden med, kom også kassen med de store cigarer frem på disken. Det skete også, når der skulle købes ind til en datters udstyr, hvor traditionen foreskrev, at der skulle være tolv af hver (dynebetræk, både hvide og kulørte, lagner, pudevår), foruden duge, dyner og puder og måske et gulvtæppe. Sådanne dage kunne der være én eller flere plovmænd (500 kr.-sedler) i kassen. Det var sjældent, så store sedler blev set $\mathrm{i}$ omløb.

De nævnte afdelinger var salgs- og indkøbsafdelinger, men hertil kom en række serviceafdelinger. Systuerne påtog sig opgaver for alle salgsafdelinger, dog havde herreafdelingen aftale med lokale skræddermestre om større forandringer af herrekonfektion. Stor selvstændighed var tillagt dekoratøren, der

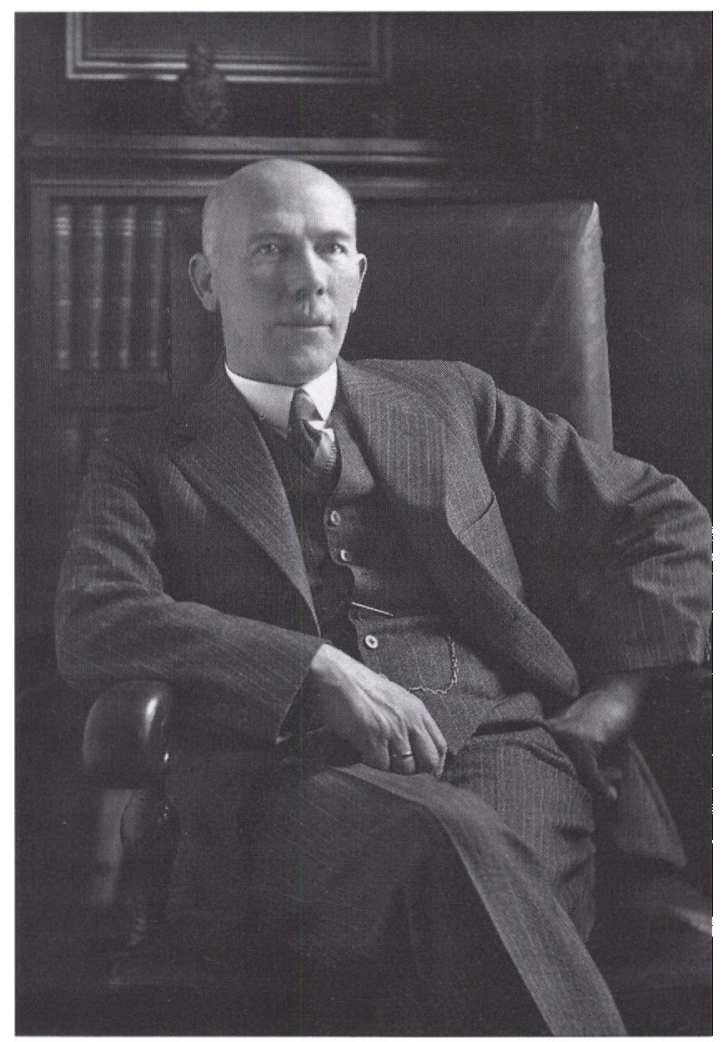


havde et betydeligt ansvarsområde med de mange udstillingsvinduer og de store lokaler. Bogholderiet var personalemæssigt af begrænset størrelse. Her arbejdede alene bogholderen assisteret af kasserersken. Alt blev ført $\mathrm{i}$ hånden i store bøger. Det var et enkelt opbygget bogholderisystem med statusbog, kassejournal og konti for leverandører og kunder m.v. Først efter 2. verdenskrig føltes der behov for et maskinelt bogholderi med løsblade. Et samarbejde med en statsautoriseret revisor indledtes først i 1942, da interessentskabet blev dannet. I de første år var hans opgave ikke at kontrollere bogføringen, men alene at udarbejde de fornødne opgørelser til skattevæsenet. Der fandtes to kasseapparater, ét ved hovedindgangen og ét i herreafdelingen. Ved hovedkassen var der fast kassererske, der også varetog visse bogføringsopgaver. Ved siden af fandtes pakkebordet, hvor købte varer pakkedes ind og blev udleveret. I den første forretning var kassen blot en skuffe under en disk. I den nye anskaffedes Nationalkasseapparater, i første omgang til at betjene med et håndtag, senere kom de elektrisk virkende. På 1. sal fandtes et fjerkammer. Her opbevaredes fjer og dun dels i store beholdere og dels i papirposer. Det var almindeligt, at kunden selv søgte bolster ud, både til under- og overdyne, lang- og hovedpude. Og selv efter prøver afgjorde, hvilket fyld, der skulle i.

En vigtig funktion var naturligvis indkøbene. Det almindelige var, at repræsentanter og agenter (rejsende, som de kaldtes) blot henvendte sig i butikken med deres tasker og prøver i håb om at kunne få lov til at vise dem frem. Faste forbindelser aftalte tid i forvejen. Normalt fandt indkøbene sted i butikslokalet, medens reprasentanter for de store konfektions- og kjolefirmaer ofte indlogerede sig på Grand Hotel, hvor kollektionen blev forevist. Mange rejsende besøgte trofast år efter år forretningen, repræsenterende det samme firma og blev »venner af huset«, hvilket dog kun yderst sjældent udviklede sig til venskab eller selskabeligt samvær i hjemmet. Forretning for sig og hygge for sig var det klare budskab, og privatsfæren var noget helt tredje.

At kunne præsentere kunderne for de varer, de ønsker mest, og helst vil købe, er en væsentlig forudsætning for succes. Indkøb er derfor en væsentlig funktion i enhver forretning.

Selvom en del indkøbsfunktioner var uddelegerede, fulgte Peter Jessen med stor interesse indkøbene. Han var altid med, når der indkøbtes damekonfektion og kjoler, og ofte når det gjaldt andre større indkøb, eller når en ny forbindelse skulle optages eller en gammel forbindelse udgå. Nogle gange om året blev der foretaget indkøbsrejser til København for at se kollektioner og købe ind hos fabrikanter og modehuse. Det gjaldt også, når fabrikanter holdt udsalg i slutningen af en sæson. Mål for indkøbsrejser var også Herning, Silkeborg og Aarhus, men det almindelige var, at de rejsende regelmæssigt aflagde besøg med prøver og tilbud. 
På salgssiden blev der lagt vægt på en venlig og omhyggelig betjening af kunden og en god service. Kunder kunne få prøver med hjem og varer i udvalg, så man hjemme i ro kunne overveje, hvad der skulle købes. Varer ombyttedes, hvis de da ikke havde været brugt, og mange opnåede rentefri kredit, adskillige havde løbende måneds- eller kvartalskonti. Det var en selvfølge, at kunderne fik varerne leveret, når og hvor de ønskede det. Kunder modtoges med et smil og venlighed, og efter salgets afslutning fulgtes kunden til døren ligeledes med tak, buk og et "på gensyn«. Langt de fleste varer hang eller lå utilgængelige for kunderne på stativer, på hylder i diske bag glas eller i skuffer, hvorfor kunderne var henvist til ekspedientens evne og villighed til at finde det rigtige frem.

Straks om morgenen orienterede Peter Jessen sig hos bogholderen om, hvordan de aktuelle finanser stod og om hvilke større dispositioner, der forestod. Resten af dagen var han ivrigt optaget af forretningens mange aktiviteter, også med at underholde kunder og animere til køb, almindeligvis rygende en stor cigar, hvilket ingen syntes at tage anstød af.

\section{Krig og besættelse}

I de år, artiklen her omfatter, var ikke så få af byens borgere tysksindede, en naturlig konsekvens af byens beliggenhed i grænselandet. I 20'erne og 30'erne opnåede tyske lister ved valgene mellem 27 og $34 \%$ af samtlige afgivne stemmer. Der var tale om et ret stærkt tysk islæt i byen, og helt frem til 1945 var det almindeligt, at tyske familier, der ønskede det, blev betjent i forretninger på det tyske sprog.

Forholdet mellem danske og tyske $\mathrm{i}$ byen påvirkedes naturligvis af den nationalpolitiske udvikling, men i hverdagen levede man side om side og tog dagliglivets tørn. En del danske familier handlede kun hos danske handlende, og tilsvarende købte en del tyske familier kun ind hos tyske forretningsdrivende, men der var også mange familier, der ikke tog sådanne nationale hensyn og købte, hvor de fandt bedst. Generelt kan det siges, at der stod størst respekt omkring de personer, der klart bekendte sig som enten danske eller tyske, medens de såkaldte »blakkede«, som man ikke vidste, hvor stod, mødtes med mindre respekt. Peter Jessen lagde aldrig skjul på, at han var dansk og havde trods dette, mange tyske kunder.

Nationalsocialismens fremmarch i Tyskland i 30'erne og besættelsen i april 1940 medførte uundgåeligt en skærpelse af den nationalpolitiske spænding, hvilket også smittede af på samvær og kontakt mellem danske og tyske i byen. Afstanden blev større. Forretningsmæssigt fandt en vis hamstring sted både 


\section{Peter Jessen, Aabenraa MANLFIKTKK
KONFEKTIUN}

ved krigsudbruddet og ved besættelsen. Mange sønderjyder huskede så udmærket den store varemangel under den første krig. Forretningerne søgte bedst muligt at foretage ekstraordinære indkøb, men muligheden herfor svandt hurtigt ind på grund af mangel på råvarer, og fordi fabrikker $\mathrm{i}$ Tyskland og $\mathrm{i}$ de tysk besatte områder omstilledes til krigsproduktion.

Selvom der indfortes visse rationeringer også af textilvarer, og der gennemførtes en produktion af standardtøj, tømtes lagrene alligevel ret hurtigt, og ved årsskiftet 1942/43 var hylderne i textilforretningerne tomme. I økonomisk henseende betød denne udvikling, at de velkonsoliderede forretninger fik frigjort kapital. Der var jo ingen varer at sætte penge i. Da det var uinteressant at placere denne noverskydende" kapital i bankerne, fordi renten var ekstrem lav, eller der slet ikke betaltes nogen, søgtes ofte andre muligheder for placering af den midlertidigt ledige kapital. Peter Jessen valgte at investere i fast ejendom og i danske aktier. Han havde jo selv oplevet den tyske inflationsperiode ved første verdenskrigs afslutning på nært hold. Han købte således i de år forretningsejendommen Storegade 8 og en villa på Jørgensgård, foruden skovparceller i Stubbæk og ved Agerskov samt et jordareal i Bovlund Enge, et areal, der kom fra hans fædrene gård i Vellerup.

Der var tale om midlertidige investeringer, og disse ejendomme solgtes da også efter krigen $\mathrm{i}$ takt med behovet for frigørelse af kapital til forretningens drift. I 1946 købte Peter Jessen af svogeren, amtslæge dr. med. Mads Michelsen, naboejendommen Storegade 19, hvor herreafdelingen hidtil havde haft til leje. I 1942 overtog Aabenraa Manufakturlager en mindre strikvarefabrik beliggende i Kølkær ved Herning. Det skete for ad den vej at sikre Aabenraa Manufakturlager en øget varetilførsel, men også i håb om på længere sigt at 
kunne oparbejde en egenproduktion af strikvarer til damer og børn. Varerne markedsførtes under navnet Acorn.

Besættelsen medførte også visse ændringer i medarbejderkredsen. Flere af de første års betroede medarbejdere søgte andet virksomhedsområde, men en ny generation ledere og mellemledere voksede op ${ }^{2}$. I 1941 kunne der i alt tælles 35 medarbejdere i detail- og engrosforretning. I 1939 tiltrådte Peter Jessens ældste søn Johan Jessen en stilling i detailforretningen, men overtog i 1942 ledelsen af Aabenraa Manufakturlager. Den næstældste søn Erik Jessen tiltrådte en stilling i detailforretningen i 1943.

\section{Efterkrigsårene}

Også efterkrigsårene betød unormale handelsforhold. Behovet for varer var stort. De private husholdninger havde $\mathrm{i}$ flere år slidt på tøjet uden at kunne foretage reelle fornyelser. Danske fabrikker kom på grund af råvaremangel kun langsomt $i$ gang, så interessen samlede sig om at finde varepartier $i$ udlandet. Firmaet foretog en del indkøbsrejser til England, hvor man, selv om landet havde været stærkt ramt af krigen, kunne trække på de muligheder, Commonwealth bød på. Disse indkøbsrejser gav dog kun begrænsede resultater, men i 1946 opstod der nye muligheder, idet der da kunne gennemføres såkaldte varebytteforretninger. Det var rene byttehandler. Der indgik ingen penge. Man byttede varer. Typisk var der tale om f.eks. at bytte fisk med spanske eller italienske kjolestoffer og bløde hvidevarer. Disse forretninger var for store til, at Peter Jessen kunne gennemføre dem alene. De blev da også almindeligvis organiseret af agenter og grossister, der sad inde med de rigtige kontakter og formåede at kombinere mulighederne.

Peter Jessen deltog $\mathrm{i}$ stort omfang $\mathrm{i}$ disse forretninger, der forudsatte, at deltagerne var i stand til at betale ofte måneder, før varerne blev leveret. En vis risiko var der således, men Peter Jessen kom igennem uden at notere større tab og blev i stand til at tilbyde ret store partier til de varehungrende kunder. De største indkøb omfattede lagenlærred, dynebetrækstof, vistrastoffer til gardiner og kjoler, dame- og herrecottoncoats, grønne oilskinsfrakker og flere store trækasser fulde af australske herresokker, de to sidstnævnte formentlig rester fra militærets lagre. Som kuriosum kan nævnes et parti småternet uldstof, der blev syet til herrejakker. Det blev til så mange, at den blev kaldt Aabenraa-jakken, samt et større parti herrehatte, der dog viste sig at være meget langsomt omsatteligt.

Disse store varekøb blev et kærkomment supplement til de faste leverandørers løbende leverancer. Mange varer var hurtigt solgt igen til de "sultne« 


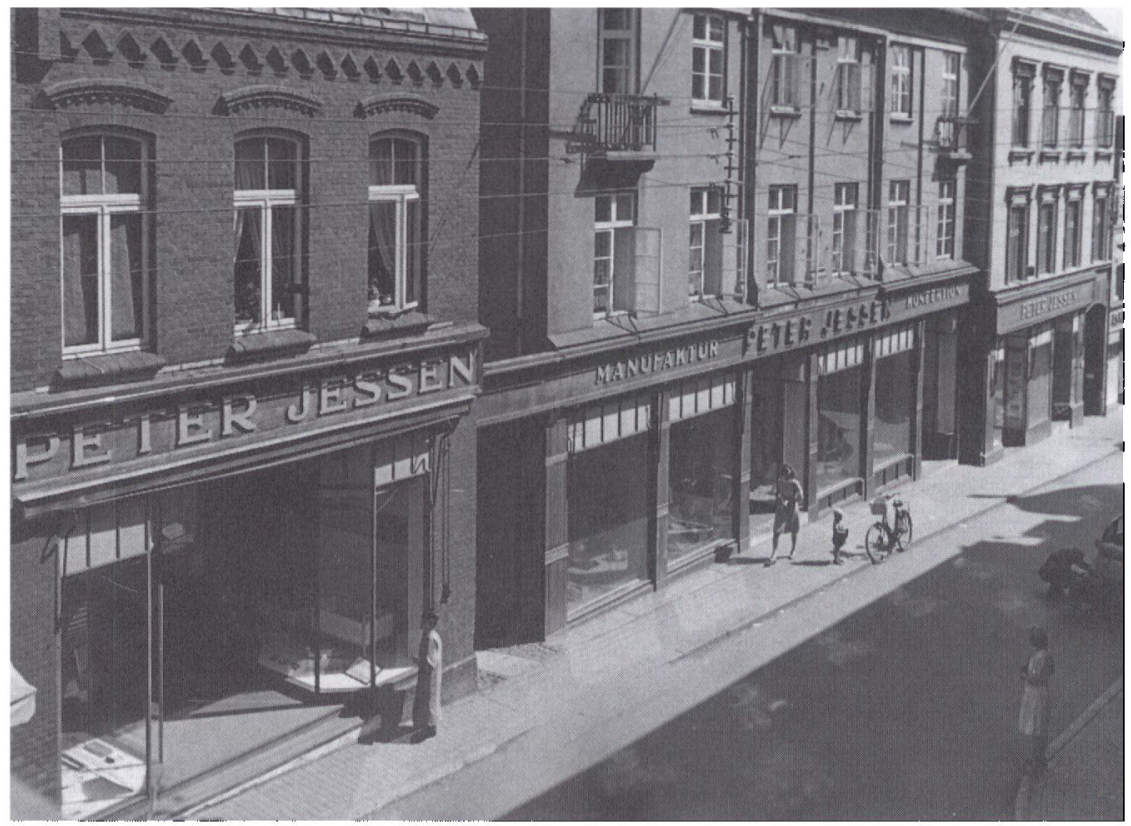

Forretningens facade fotograferet under besattelsen. Til venstre de lejede lokaler $i$ Storegade 15. Derefter folger hovedbygningen. hvis facade svarer til den oprindelige fra 1923. Til hojre Storegade 19. hvor herre- og drengeafdelingen havde til huse. Pà gaden helt til hojre ses en tysk soldat, der er ved at reparere sin bil.

kunder, hvilket medførte en stærk vækst i salget. I 1939 nåede salget knap 1 mio. kroner. I 1947 blev det på 2.7 mio. kroner og i 19493.2 mio kroner.

I 1951 kunne Peter Jessen fejre 40 års jubilæum. Det skete foruden ved jubilæumstilbud og modeopvisning også ved en større fest for medarbejdere på Grand Hotel, men Peter Jessen havde også grund til at være tilfreds. Salget gik fint og nåede i 1952 nær de fire millioner, hvortil kunne lægges et salg $\mathrm{i}$ Aabenraa Manufakturlager på 1,5 million, hvoraf halvdelen var egen strikvarefabrikation. I vurderingen af disse tal bør der tages hensyn til, at der under krigen og i årene derefter var tale om en del prisstigninger, der tog særlig fart under Koreakrigen 1950 - 53. I medarbejderskaren, der nu i alt nærmede sig 50 , skete der naturligt løbende ændringer ${ }^{3}$.

I 1950 foretoges en udvidelse af udstillingslokalerne, idet Peter Jessen i ejendommen Storegade 15 lejede yderligere lokaler til udstillingsformål. Omkring samme tid købte Aabenraa Manufakturlager H.P. Hanssens hus i Nygade, der blev indrettet til lager og til strikvarefabrikken, der samtidig flyttede dertil fra Kølkær. 


\section{Organisationsform}

Firmaet blev drevet som et personligt ejet firma indtil 1942, dog udskiltes Aabenraa Manufakturlager i 1936 som et særskilt aktieselskab. I 1942 fandt Peter Jessen tiden inde til at andre firmaet til et interessentskab, hvori han også optog de fem børn. Interessentskabet omfattede kun forretningen, idet ejendommen forblev privat ejendom, der udlejedes til interessentskabet.

Interessentkapitalen blev fastlagt til 360.000,- kr., hvoraf Peter Jessen ejede $3 / 8$ og hver af børnene 1/8. I 1952 forberedtes omdannelsen til aktieselskab, en omdannelse, der blev konfirmeret $\mathrm{i}$ foråret 1953 nogle måneder før Peter Jessens død. Aktionærerne var fortsat Peter Jessen og de fem børn. Efter Peter Jessens død overtog fru Anna Jessen hans aktiepost. Aktiekapitalen blev fastlagt til $800.000 \mathrm{kr}$.

\section{Andre opgaver}

Det er forståeligt, at der også fra anden side var bud efter den driftige købmand med den hurtigt voksende forretning, og Peter Jessen sagde ikke, som andre af erhvervslivets folk, nej.

Allerede i 1920 fik han de første tillidsposter, idet han blev udpeget som suppleant for borgmester Holger Fink i repræsentantskabet for den nyoprettede Sønderjyllands Kreditforening og tilsvarende i bestyrelsen for Ad. Greve Brockenhuus-Schacks Genforeningslegat. Fra 1922 til 1925 var Peter Jessen formand for ligningskommissionen og Hjælpekassen i Aabenraa og indvalgtes i 1925 i byrådet på den borgerlige fællesliste som repræsentant for Det konservative Folkeparti. I byrådet, hvor han sad indtil 1946, da han ikke ønskede at fortsætte, var han medlem af magistraten (økonomiudvalget) og viste særlig interesse for arbejdet $\mathrm{i}$ havneudvalget, skoleudvalget og for udviklingen på Aabenraa Sygehus. I en del år var han medlem af bestyrelsen for Sønderjyllands Højspændingsværk. Han var en trofast deltager i Aabenraa Handelsstandsforenings møder og deltog aktivt $i$ de landsdækkende møder $i$ Dansk Provinstextilhandler Forening og Dansk Textil Union.

Udviklingen $\mathrm{i}$ hans egen by, Aabenraa og dens omegn påkaldte sig naturligvis også interesse. Han tegnede aktier og andele i Grand Hotel, da det blev bygget, i Hotel Royal og Sønderjyllandshallen, ligesom han ydede bidrag til danske aktiviteter på egnen f.eks. til Løjt Sogns Forsamlingshus, Risehus og Søgårdhus m.fl. Han og familien var trofaste deltagere i Frederiksklubbens arrangementer, og han var med til at stifte Aabenraa Rotary Club. I 1950 blev han valgt til formand for Den Nordslesvigske Folkebanks bestyrelse. Arbejdet 
i Det konservative Folkeparti omfattede han med stor interesse og hørte i mange år til partiets trofaste støtter, både lokalt og på landsplan. En enkelt gang var han valgmand ved et landstingsvalg, men brød med partiet eller rettere med Christmas Møller, da denne efter besættelsen anlagde sin yderst negative holdning over for Sydslesvigs fremtid.

Under besættelsen undgik Peter Jessen ikke bekendtskabet med Gestapo og dets danske hjælpere, idet man efter sabotagen på Callesens Motorfabrik i februar 1944 foretog en omfattende husundersegelse på Bramsbjerg, hvor man troede, at den eftersøgte overretssagfører Holger Boeck opholdt sig. Det var nu ikke tilfældet, men den 31. maj kom Gestapo igen og arresterede Peter Jessen og alle fire sønner (Olaf i Aarhus og Peter Christian i Sønderborg) mistænkte for at have kendskab til våbentransporter.

Efter få dages arrestation blev alle dog løsladt, men Gestapos spor var ikke helt forkert, idet disponent Hans Mørup var medlem af modstandsbevægelsens syd- og sønderjydske regionsledelse. Han undgik ikke arrestation og måtte døje næsten otte måneders ophold $\mathrm{i}$ tyske koncentrationslejre, men nåede lykkeligvis hjem ved krigsafslutningen. I 1950 blev han manufakturhandler $\mathrm{i}$ Faaborg.

I foråret 1953 konstateredes det, at Peter Jessen led af lungekræft. En operation fik ikke bugt med sygdommen, og Peter Jessen sov stille hen på Bramsbjerg i juli, kun 67 år gammel. Men han følte selv, at han havde haft et godt og indholdsrigt liv.

Peter Jessens virksomheder eksisterer ikke mere. Aabenraa Manufakturlager med strikvarefabrikken Acorn blev efter et nybyggeri på Østre Havnevej, i 1959 overtaget af Johan Jessen, men måtte lukke i slutningen af 60'erne.

Detailforretningen ophørte i 1989 efter 78 års virksomhed og led derved samme skæbne som næsten alle andre tilsvarende forretninger i provinsen. Med det brede vareudvalg og den omfattende service blev de for omkostningstunge i forhold til de opdukkende storbutikker og supermarkeder, der byggede på selvbetjening, hurtig omsætning, ringe service og lave priser.

En anden konkurrence mødte de blandede forretninger fra et stærkt stigende antal specialforretninger, mange som led i landsdækkende kæder, der overtog store dele af salget i tæpper, herretøj, damekonfektion og kjoler samt modevarer.

De blandede manufakturforretninger i de danske købstæder havde haft deres tid. 


\section{NOTER}

1. I 1959 solgte Anna Jessen ejendommen. Den blev derefter benyttet som eksternatskole for psykisk handicappede bern.

2. Prokurist Johannes Andresen, der i 1920 havde beholdt sit tyske statsborgerskab, søgte andet virksomhedsområde, hvilket også den mangeårige medarbejder, Mathias Frost gjorde. Andresen var i mange år derefter bosat i Sydslesvig, og Frost åbnede nogle år efter krigen en damekonfektionsforretning i Vestergade i Aabenraa. Af de ledende medarbejdere herefter kan foruden de tidligere nævnte Georg Petersen, Peter Sørensen, Maren Madsen, Christian Beck og Ellen Rasmussen, nævnes Dagmar Brandt, Olaf Christensen (der senere drev gardinforretning i Nørreport), Detlef Clausen (senere hos Orbesen i Haderslev), Kaj Grønfeldt, (senere manufakturhandler i Gelsted), Margrethe Hansen (kassererske), Hans Mørup, Emil Schmidt og Wilhelm Wernicke, der senere drev manufakturforretning i Svinget.

3. Foruden sønnerne Olaf og Peter Christian Jessen kan af de mere ledende medarbejdere nævnes Edith Buch (kjoleafdelingen), Peter Christensen (herreafdelingen), Aksel Frederiksen, Arne Hansen, Memborg Knudsen, Helge Kristiansen og Gunder Petersen (systuen).

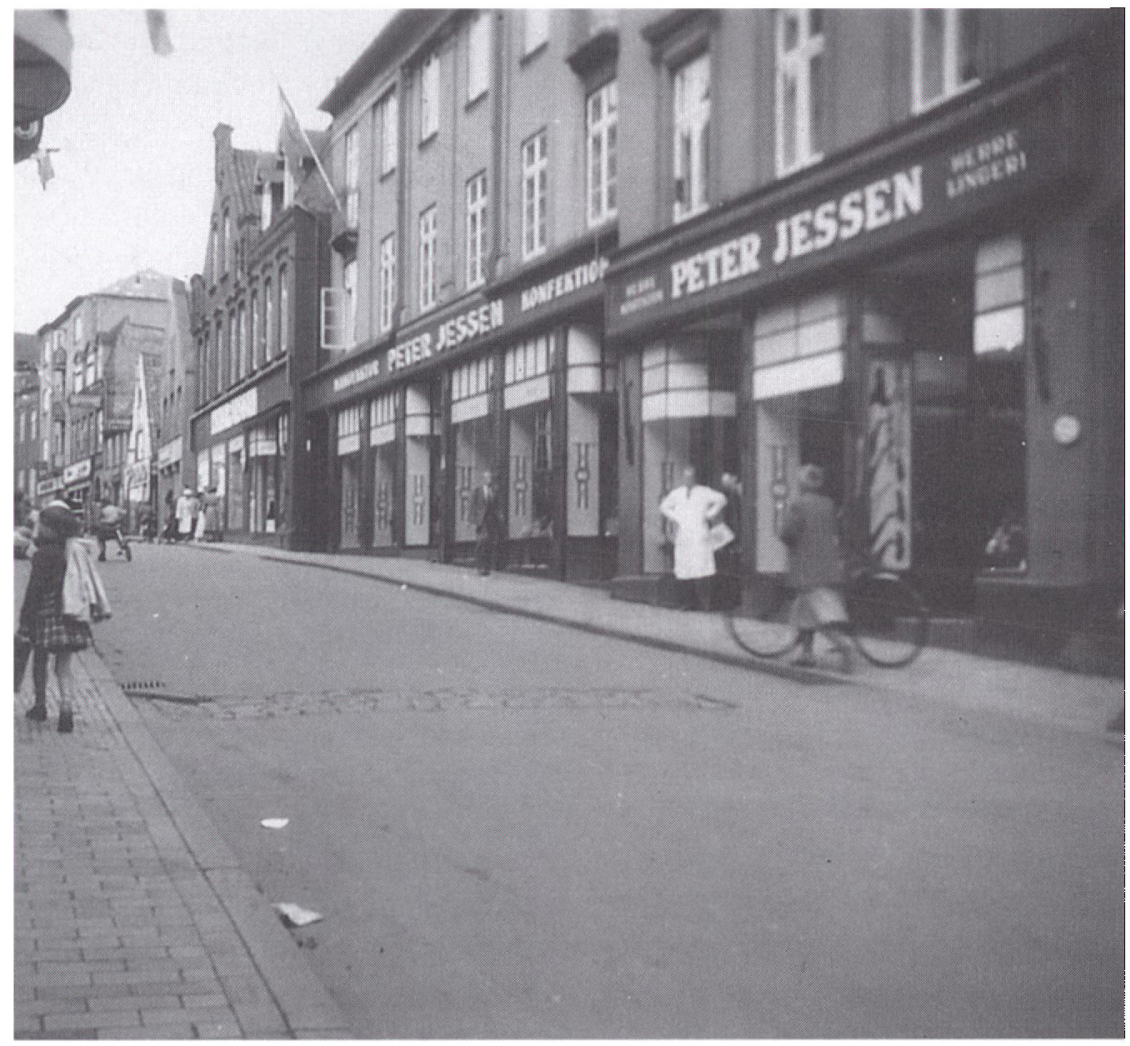

Forretningen set sydfra i 1951. Helt tilhage i billedet ses de nye udstillingslokaler, der netop er taget $i$ brug. 